\title{
A VIDA DOS LUGARES ENTRE OS KÏSÊDJÊ: TOPONÍMIA COMO TERMINOLOGIA DE RELAÇÃO
}

MARCELA STOCKLER COELHO DE SOUZA ${ }^{1}$

$U n B$

\begin{abstract}
RESUMO: Este artigo trata da toponímia kïisêdjê (povo indígena de língua jê também conhecido como Suyá) por meio da suspensão de duas assunções: a de que os lugares sejam produtos de processos, seja de construção, seja de representação; e a de que nomeá-los seja um modo dessa construção. O que tento mostrar é que os lugares a que se referem os topônimos são constituídos a partir de relações, que se poderia dizer intersubjetivas ou interpessoais, entre humanos e não humanos, e entre humanos eles próprios; e que nomear os lugares é um tipo de ação ou atividade que participa dessa constituição. Nomear os lugares, assim como narrar as histórias que se conectam a eles e a seus nomes, constitui relações entre pessoas (humanas e não humanas) com respeito a outras pessoas (idem), e é esta teia viva de relacionamentos que faz um lugar (enquanto um objeto de atenção para os sujeitos). Como acredito que terminologias de relacionamento e onomásticas façam, entre outras coisas, o mesmo (constituir pessoas como objetos da atenção de outras a partir de suas mútuas relações), é o interesse em explorar essa analogia que o título do artigo vem sinalizar.
\end{abstract}

PALAVRAS-CHAVE: toponímia; lugares; povos Jê; onomástica; história.

\section{The life of places among the Kïsêdjê: Toponymy as a terminology of relationship}

\begin{abstract}
The present study focuses on the toponymy of the Kïsêdjê (Brazilian indigenous Jê speaking people, also known as the Suyá) based on two assumptions: places are the result of processes, whether of creation or of representation; naming is one of the ways by which places made. I am at showing that the places referred to by the toponyms are the product of (intersubjective, interpersonal) relationships, happening between humans and non-humans, as well as among humans themselves; as well as that the naming of places is an action or activity which takes part in those relationships. The naming of places, like the telling of stories which connect with places and their names, is a way of building relationships between (human and nonhuman) persons, concerning other (human and non-human) persons. That living web of

\footnotetext{
${ }^{1}$ Professora do Departamento de Antropologia da UnB desde 2006, possui mestrado e doutorado em antropologia social pelo PPGAS do Museu Nacional/UFRJ. Atua na área de Antropologia, com ênfase em Etnologia Indígena, em uma colaboração de longo prazo com o povo Kisêdjê. É coordenadora do Laboratório de Antropologias da T/terra (Tterra). E-mail: macoelhosouza@gmail.com .
} 
relationships is what places are made of, as objects of the subject's attention. The title of the study points at my intention of exploring a belief that terminologys of relationship and onomastics have the same function (among others), which is to constitute persons as objects of one another's attention through mutual relations.

KEYWORDS: toponymy; place; Jê peoples; onomastics; history.

La réalité que j'avais connue n'existait plus. Il suffisait que Mme Swann n'arrivât pas toute pareille au même moment, pour que l'Avenue fût autre. Les lieux que nous avons connus n'appartiennent pas qu'au monde de l'espace où nous les situons pour plus de facilité. Ils n'étaient qu'une mince tranche au milieu d'impressions contiguës qui formaient notre vie d'alors; le souvenir d'une certaine image n'est que le regret d'un certain instant ; et les maisons, les routes, les avenues, sont fugitives, hélas ! comme les années.

(Marcel PROUST, Du coté de chez Swann, 2015 [1913], p. 233).

\section{Prólogo 2}

Em uma visita, em novembro de 2007, ao sítio de uma aldeia antiga (chamada Rop Hwïká Kapaj Tá, "onde tiraram a canoa da onça“), deixado de fora da terra oficialmente demarcada, mas em área sempre ocupada - e presentemente reivindicada - pelos Kïsêdjê, surpreendi-me ao encontrar, na base de uma árvore recentemente derrubada, a seguinte inscrição: "Ngrwatxikhô (Buritizal Grande): foi aqui que Orlando e Cláudio

\footnotetext{
${ }^{2}$ Este texto tem uma longa história, desde uma primeira comunicação apresentada em 2009 em Lisboa, que foi sendo desdobrada em algumas outras ocasiões. Chegou a ter certa circulação, em uma versão prépublicação (COELHO DE SOUZA, 2009); aparece aqui um pouco reformulado, para facilitar a leitura de dois outros textos que na verdade desdobraram-se dele (COELHO DE SOUZA, 2014 e 2017). Agradeço a todas as pessoas com quem pude discutir essas ideias ao longo desses anos, especialmente os alunos do PPGAS/UnB, em uma série de cursos sobre a temática da terra. André Villas-Bôas, do Instituto Socioambiental, e Anthony Seeger fizeram faz tempo leituras cuidadosas que não esqueci. Desenvolvo pesquisa com os Kïsêdjê desde 2004; agradeço a todos eles, e elas, o privilégio.
} 
nos encontraram pela primeira vez". Perguntei ao chefe (cujo pai fora quem abrira esta aldeia no início da década de 1950): por que Ngrwatxikhô? O que aconteceu com o nome antigo? Ele contou-me que seu filho então adolescente achara que o nome estava muito velho, e decidira renová-lo: "temos agora uma casa e uma roça novas neste lugar, então precisamos de um novo nome para ele; e, olhe em volta, as palmeiras buriti são grandes aqui”. De volta à aldeia principal, todas as vezes que escutei as pessoas mencionarem a nova roça do chefe, referiam-se ao sítio como Ngrwatxikhô.

Agora, uma das provas que se espera seja produzida pelos antropólogos, quando chamados a atestar a tradicionalidade da ocupação indígena de uma área, é uma lista de topônimos, associados aos eventos ali transcorridos, recursos disponíveis e outras informações que componham o conhecimento que o povo em questão tem de cada sítio. O hábito de mudar os nomes dos lugares é, neste contexto, tão irritante quando o costume comparável de esquecer os nomes dos mortos, ou de multiplicar os nomes dos vivos, para a antropóloga tentando construir suas preciosas genealogias - mas com consequências políticas mais sérias. Relatórios de identificação e documentos do tipo são - no caso kïsêdjê, pelo menos - cheios de pequenas inconsistências derivadas da dupla ou tripla nomeação de um mesmo lugar, ou da recorrência de um mesmo nome para diferentes lugares. Isso não perturba os Kïsêdjê, mas outros apressam-se em explorar essas inconsistências de modo a contestar suas reivindicações fundiárias.

Disso deriva o interesse presente dos Kïsêdjê em produzir uma documentação abrangente do conhecimento que têm do território. Como outros povos amazônicos, perceberam que precisam de alguma forma tornar esse conhecimento visível a forasteiros, e querem ver reconhecidos como seus os lugares e paisagens que habitam. Ao mesmo tempo, uma miríade de reticências, omissões e hesitações, marcadas pelo receio explícito de que esses registros sejam usados contra eles, ou pela percepção de que boa parte de seu conhecimento é incompreensível ou 
irrelevante para essa nova audiência, evidencia a diferença entre o modo como falam da terra entre si e com outros. Uma diferença que pude experimentar diretamente.

Em maio daquele mesmo 2007, em quatro barcos movidos a motor, cerca de 30 Kisêdjê (homens e mulheres, velhos, adultos e crianças) tinham empreendido uma expedição de uma semana ao alto curso do rio Suiá-Miçu, área que ocuparam durante a primeira metade do século XX. Os objetivos da viagem eram múltiplos: coletivamente, tratava-se de fazer um registro da memória dos velhos - em duas câmeras manejadas por cineastas indígenas - e um monitoramento das condições das águas e matas de seus antigos territórios. De sua parte, os mais velhos nascidos no alto Suiá-Miçu - ansiavam sobretudo por rever os lugares de sua infância e juventude; os mais jovens, por pisar nos cenários de histórias tantas vezes ouvidas. A antropóloga tinha seus próprios motivos - aprender o suficiente para poder escrever um texto como este, por exemplo. As duas assessoras do Instituto Socioambiental, operando o GPS, e tendo articulado a passagem de nossa caravana por um assentamento localizado no sítio de uma aldeia antiga, esforçavam-se ao mesmo tempo para auxiliar os Kïsêdjê em seus projetos de documentação e revitalização de seu conhecimento territorial, e para fortalecer, por meio dessa viagem de vigilância e monitoramento ambiental, a aliança entre os índios e outras comunidades locais no sentido da proteção e recuperação das nascentes do rio Xingu e de seus formadores ${ }^{3}$. A toponímia aqui discutida foi obtida ao longo desta viagem, bem como de outras realizadas durante os trabalhos do Grupo Técnico constituído pela Funai naquele mesmo ano para identificação da área kïsêdjê que ficou de fora da Terra Indígena Wawi, demarcada na década de $1990^{4}$.

\footnotetext{
${ }^{3}$ No contexto da campanha Y Katu Xingu, "Água Boa do Xingu", desenvolvida por iniciativa do ISA e outras instituições desde 2004, e que teve como desdobramento importante a criação da Rede de Sementes do Xingu, em 2007 (informações sobre essas iniciativas podem ser encontradas no site do Instituto Socioambiental, <https://www.socioambiental.org/pt-br>).

${ }^{4}$ Uma segunda expedição à mesma região, com objetivos similares, foi realizada em 2012, igualmente apoiada pelo ISA e desta vez no âmbito de um projeto apoiado pelo IPHAN (COELHO DE SOUZA, 2014). Como coordenadora do GT, fiz ao todo quatro viagens pelo território reivindicado, percorrendo todo o rio
} 
Anthony Seeger (1981) conta que, nos anos 1970, durante as expedições de caça e pesca, os Kïsêdjê, depois de Ihe ensinarem os nomes dos lugares, sabatinavam-no intensivamente para averiguar 0 quanto aprendera: "como é nome do lugar onde matamos o jacu ontem?"; "onde dormimos?"; "onde paramos para banhar?". Em todas as viagens que fizemos, embora ensinar-me (e aos demais não-indígenas) fosse parte do pretexto para a ocasião e o aparato (gravadores, GPS...) que carregávamos, o meio das lições era sempre outro. Era a conexão entre o homem mais velho, que contava o nome e narrava a história, e um seu parente mais jovem (filho, sobrinho) a quem invariavelmente se dirigia: "aqui chama..." - e diz o nome do lugar, completando: "foi aqui que seu avô tirou casca de jatobá para fazer canoa"; ou "foi aqui que seu avô, meu tio, flechou o khupë ("indio", "outra gente") fulano"; ou "foi aqui que o kupë sicrano matou sua avó". A isso se seguia um relato dos acontecimentos, rico em detalhes concernentes à sequência das ações, nomes (de pessoas, de outros lugares), descrições e comentários sobre elementos (presentes ou passados) da paisagem. Finalmente, alguém fosse o homem sênior, fosse seu parente mais jovem - repetia-me cuidadosamente o nome do lugar e o resumo condensado (e despersonalizado) dos eventos em questão: "foi aqui que o pessoal de antigamente matou inimigos" - especificando, após meu perguntar insistente, "quais, quando?" - "quando moravam no Hore nhõ ngô" - e, depois de mais alguma insistência, "quem?" - "o avô de fulano, pai de sicrano". A imensa defasagem entre minhas ralas notas tomadas então e a riqueza dos relatos feitos aos parentes jovens só me ficou evidente bem depois, quando, com uma compreensão um pouco maior da língua, pus-

\footnotetext{
Pacas (nas margens do qual se situa atualmente a principal aldeia kïsêdjê) bem como o curso do baixo SuiáMiçu (limite da expedição anterior). A esses dados, posteriormente retrabalhados com diversos colaboradores e assistentes de pesquisa, foram juntadas algumas informações constantes na bibliografia (especialmente SEEGER, 1981, p. 47-55, 75-77; PECHINCHA, 1996). Os trabalhos do GT foram interrompidos várias vezes por liminares sob o argumento de "parcialidade" da antropóloga coordenadora. Uma decisão de mérito foi publicada em 2015, revogando a portaria de constituição do grupo, desta vez com base em uma interpretação abrangente das condicionantes da sentença do STF quanto à Raposa Serra do Sol, aquela que proibiria a "revisão de limites" que implique ampliação da terra indígena.
} 
me a escutar as vozes quase abafadas pelo motor do barco nas gravações.

Cartas geográficas e registros escritos, é evidente, materializam o conhecimento indígena sob formas muito diferentes daquelas por meio das quais este se formula e transmite localmente. Em lugar de nomes mutáveis e narrativas enunciadas por pessoas particulares, em momentos determinados, para ouvintes específicos, temos agora mapas, relatórios, laudos, bancos de dados - representações que podem certamente ter seu valor estratégico, mas cujos efeitos colaterais devem ser cuidadosamente ponderados, já que criam uma diferença (entre elas próprias como representação e aquilo que por elas seria representado) que o modo indígena de conhecimento parece justamente elidir ou evitar. Símbolos que "representam a si mesmos" (WAGNER, 1986), os lugares nomeados kïsêdjê não existem fora das relações (dos relacionamentos) que os animam, e por meio das quais são narrados. Este é o ponto de partida da presente reflexão ${ }^{5}$.

Os Kïsêdjê chegaram no Suiá-Miçu, afluente oriental do rio Xingu, no início do século XX; haviam penetrado a bacia do Xingu pelo leste, talvez 100 anos antes disso. Embora conservem a memória de aldeias e trajetórias anteriores, consideram estes rios - sobretudo o Suiá-Miçu e seus afluentes - como seu "território tradicional" (como dizem em português), área em que se concentram seus wapatá thumu ("nossos lugares/aldeias antigos"): uma rede de lugares nomeados que inclui aldeias, acampamentos, roças, áreas de concentração de "recursos", sítios de eventos memoráveis, etc. ${ }^{6}$. No final da década de 1990, os Kïsêdjê recuperaram parte desse território, de onde haviam sido transferidos na década de 1960 para o interior do Parque Indígena do Xingu (PIX), e retornaram ao sítio de uma das aldeias ocupadas por ocasião do contato

\footnotetext{
${ }^{5}$ Como disse Peter Gow, "The issue is too serious to be modelled analytically on the relationship between the thing itself and the other thing that only stands for the thing itself. The empty spaces on maps of Amazonia have already allowed to many people to pretend that nobody lives there" (1995, p. 45).

'Estritamente falando, wa-pa-tá ("permanecer" — pl,, "lugar de") é como os Kïsêdjê se referem a suas aldeias, "lugares de ficar", o que não incluiria roças, trilhas, e outros lugares nomeados (embora possa incluir acampamentos). Entretanto, chamados a rotular a lista (e o mapa) do conjunto de lugares nomeados identificados na expedição referida, esta foi a expressão empregada.
} 
em 1959. A partir dessa reconquista, oficializada com a demarcação da Terra Indígena Wawi (adjacente ao PIX, mas separada dele), inaugura-se uma nova fase da história kïsêdjê, marcada por rápidas transformações na sua forma de relacionamento com outros povos do Parque e com as agências e pessoas não indígenas com quem interagem. É nesse contexto que emerge uma intensa preocupação com esse território tradicional e com a documentação do conhecimento que têm dele.

Os Kïsêdjê contam uma quantidade de histórias que falam da aquisição progressiva dos elementos que constituem sua presente cultura: fogo, nomes pessoais, metades cerimoniais, certos rituais, plantas domesticadas (milho, batatas, mandioca). Mas a localização desses eventos lhes é desconhecida - diferentemente do que ocorre com outros povos, cujas narrativas míticas estabelecem uma estreita conexão entre sua emergência como seres humanos e lugares específicos, geograficamente identificáveis. A tradição oral dos Kïsêdjê inclui, entretanto, um rico relato de sua chegada na bacia do Xingu e do esforço para encontrar lá um espaço para si - o que eventualmente fizeram, penetrando o Suiá-Miçu e seus afluentes. Seu mapa dessa viagem consiste em uma série de topônimos que se referem a antigas aldeias, antigas roças, acampamentos de caça e coleta, trilhas e cursos d'água, e toda sorte de sítios históricos onde se deram encontros e eventos particulares (onde certas pessoas nasceram ou morreram, ou fizeram alguma coisa memorável, onde inimigos atacaram ou foram atacados, onde espíritos apareceram etc.). Seeger, que primeiro chamou atenção para esse sistema de topônimos, sublinha como "as dimensões temporais da sociedade suyá são reveladas na socialização dos domínios naturais que se encontram além de suas aldeias circulares. "A história (tempo) é lembrada por meio do espaço" (SEEGER, 1981, p. 79). Essa "história espacial" constitui, diz-nos Seeger, um "mapa cultural", cujo aprendizado permite a cada pessoa kïsêdjê "aprender a história e a arte prática de obtenção de alimentos e outros objetos de coleta" (p. 77). Talvez se deva falar também, correlativamente, em temporalização do espaço: pois cada 
ponto encontra aqui o seu lugar apenas na medida em que se insere também numa série temporal, como um acontecimento, seja antecipado seja repetido, mas cuja (atualização na) extensão é sempre inseparável de uma certa duração.

Depois de uma breve descrição dessa toponímia, faço observações sobre algumas maneiras como "histórias espaciais" desse tipo foram tratadas na literatura, de modo a criar um contraste que nos permita voltar à instabilidade e "interatividade" dos nomes de lugar kïsêdjê enquanto índices de sua natureza relacional - ou seja, da toponímia como uma espécie de "terminologia de relação", tão sujeita às vicissitudes da vida dos lugares quanto a linguagem do parentesco o é ao que ocorre na vida das pessoas.

\section{Toponímia}

Como já notou Seeger $(1981$, p. 75$)$, os topônimos kïsêdjê constroem-se em geral a partir de características ou elementos da paisagem (a conformação do rio, uma árvore imponente, a abundância de uma certa espécie vegetal); da presença de presas animais ou de recursos de coleta; e, sobretudo, de eventos e ações envolvendo antigos Kïsêdjê (e, em alguns casos, pessoas vivas). Esta última categoria, na lista de Seeger, é a mais numerosa. Encontrei ainda nomes formados a partir da referência a um animal, espírito, ser humano ou grupo, tido como habitante ou dono do lugar; e outros indicativos do uso habitualmente feito do sítio (afora uma categoria residual de nominações que não se enquadram nas anteriores). Essa classificação contém é claro ambiguidades e sobreposições. Nem sempre é fácil, nos nomes formados por referência a espécies vegetais, saber se é como "recurso" ou elemento da paisagem que eles aparecem; quando se trata de espécies animais, a dificuldade é decidir se é como presa abundante ou "dono" do lugar que figuram no nome. Há também, aparentemente, uma deriva entre a 
nomeação a partir de eventos históricos específicos e usos habituais: o nome Mben Jahôrô Tá ("lugar de tirar mel"), atribuído a um trecho de floresta já no baixo Suiá-Miçu, foi explicado a Seeger como referindo-se a um episódio específico, em que um grupo de guerreiros remando pelo rio interrompeu sua jornada para "roubar" mel neste lugar na mata. O lugar e o nome são os mesmos, mas nunca pude obter esta história; o lugar chama-se assim, dizem-me, simplesmente porque lá tinha muito mel, e quando moravam no Rikhô (aldeia habitada na década de 1980), iam lá para tirá-lo.

Tendo em mente essas sobreposições e derivações, meus 227 nomes poderiam ser grosso modo assim classificados (segue-se à tabela uma breve descrição, não na mesma ordem):

Tabela 1: Categorias de nomes de lugar (segundo frequência na lista).

\begin{tabular}{|l|l|l|l|}
\hline & Espécies animais/vegetais & & 85 \\
\hline & Eventos & & 62 \\
\hline & Paisagem & & 43 \\
\hline & Uso habitual & & 11 \\
\hline & Dono/habitante & 8 \\
\hline & Outros & & 18 \\
\hline & TOTAL & & 227 \\
\hline
\end{tabular}

Fonte: Elaboração própria.

\section{Espécies animais e vegetais}

A maior parte dos topônimos se forma a partir do nome de uma espécie animal ou vegetal e de componentes que indicam a forma de presença da espécie em questão. Estes podem ser especificamente descritivos, como -khô ("coletivo de plantas que crescem separadas"), - 
khrô ("coletivo de plantas que crescem juntas"), tãmã ("pé de"), khre ("buraco"), jasê ("ninho") ou khu ("monte de terra produzido por insetos/animais escavadores"), ou mais genéricos, como katxi-tá ("muitolugar", "lugar de muito"), nõrõ ("deitar", i.e., "leito"), nhyry ("sentar"- sing., i.e., "assento"], krï ("sentar" - pl., i.e., "assentos") e, sobretudo, pa-tá ("permanecer-lugar", "aldeia“), nhõ ngô ("água de") e nhõ pá ("mato de"). Seguem alguns exemplos:

$\begin{array}{ll}\text { Komnduho nhõ Ngô } & \text { Sáktxi Jasê } \\ \text { arraia POSS água } & \text { gavião-real ninho } \\ \text { Córrego da Arraia } & \text { Ninho de gavião-real } \\ \text { Atorotxi nhõ Pá } & \text { Amty Katxi Tá } \\ \text { Macuco POSS mato } & \text { marimbondo muitos lugar } \\ \text { Mato do Macuco } & \text { Lugar de muitos marimbondos } \\ \text { Kahrantxi Kre } & \text { Rikhô } \\ \text { tracajá buraco } & \text { inajá-COL } \\ \text { Buraco de Tracajá } & \text { Inajazal } \\ \text { Rumswa-kambrêkê Patá } & \text { Tekákhrô } \\ \text { formiga-vermelha aldeia } & \text { taboquinha-COL } \\ \text { Aldeia da formiga-vermelha } & \text { Tabocal } \\ \text { Rumswa Ku } & \text { Hore Patá } \\ \text { formiga monte } & \text { taquara aldeia } \\ \text { Formigueiro } & \text { Aldeia da taquara } \\ \text { Komnduho-kambrêktxi Krï } & \text { Wájsy Nhyry } \\ \text { arraia-vermelha-AUM assento } & \text { pimenta (as)sentada } \\ \text { assento das arraias vermelhas } & \text { Canteiro de pimenta }\end{array}$

\section{Donos}

Os componentes patá ("aldeia"), nhõ ngô ("água de") e nhõ pá ("mato de"), assim como huru ("roça") e (me-)krï-tá [(gente)-sentar-pl.lugar, "acampamento"] são também empregados em conjunção com 
nomes de pessoas ou coletivos humanos, indicando nesses casos uma espécie de domínio tal que esses indivíduos ou grupos possam ser ditos "donos" (khandê) dos lugares a que emprestam seus nomes. Esses nomes não se distinguem, por sua estrutura, dos anteriores, e se os constituo em categoria separada é um pouco por se referirem à presença ou ação de humanos, um pouco por enfatizarem esta última. Enquanto as explicações relativas aos nomes formados por referência a espécies animais resumem-se em geral (quando dadas para mim...) a afirmações do tipo "porque aqui tem muita arraia-vermelha", ou "porque aqui sempre estava um gavião-carrapateiro", os da presente categoria geram relatos um pouco mais detalhados. Com uma diferença adicional: a associação que eles indicam nem sempre é atual (nos casos anteriores, tende a ser), remetendo comumente a eventos e ações passados, como nos três exemplos que se seguem.

O primeiro se refere aos Awajkyry, também chamados Kupëkambrêktxi ("índios vermelhos/pardos"), considerados os originais habitantes do Suiá-Miçu, dando por isso seu nome a este rio (Awajkyry nhõ Ngô). Trata-se de um povo elusivo que já teria sido vislumbrado, mas nunca enfrentado ou visitado pelos Kïsêdjê: penetravam sorrateiramente as aldeias desses últimos para roubar perereba (mingau de mandioca), pontas de flecha e outros objetos, logo fugindo para o mato. Há muito não se percebem seus sinais. Já Djátsakárá e Khôkhôrámõrõtxi foram ambos homens (um Yaruma, outro Kïsêdjê) que, no início do século XX, abriram roças em lugares que até hoje se conhecem por estes nomes, no Suiá-Miçu e no córrego Wawi, respectivamente.

$\begin{array}{lll}\text { Awajkyry nhõ Ngô } & \text { Djátsakát Huru } & \text { Khôkhôrámõrõtxi Huru } \\ \text { Awaykyry POSS água } & \text { Djátsakárá roça } & \text { Khôkhôrámõrõtxi roça } \\ \text { Rio dos Awajkyry } & \text { Roça do Djátsakárá } & \begin{array}{l}\text { Roça } \\ \text { Khôkhôrámõrõtxi }\end{array}\end{array}$

Se relativamente pouco numerosas em minha lista, vale observar 
que expressões construídas segundo essa estrutura são comumente utilizadas em referência a aldeias, territórios e rios de outros grupos, assim como a roças de pessoas conhecidas. Nesses casos, ou nessa medida, não consistem rigorosamente em nomes próprios - assim como a expressão wapatá, "nossa aldeia", não é um nome. Em conexão com isso, vale observar que a aldeia em que Seeger fez sua pesquisa nos anos 1970, hoje denominada Setxi Patá ("aldeia Aranha“), é registrada por ele como "sem nome" (SEEGER, 1981, p. 51). Sem dúvida, não por qualquer desatenção do etnógrafo, mas porque o nome deve ter vindo depois depois, talvez, de a terem deixado. Nomear a aldeia em que se vive não parece tão importante - para os que estão vivendo lá (o fato de todas as atuais aldeias serem nomeadas poderia corresponder justamente a sua pluralidade). Mas pode ser que expressões comuns usadas para designar esses lugares se convertam em nomes mais tarde. Essa é uma questão que meus materiais não permitem averiguar.

\section{Paisagem}

Uma terceira categoria de nomes engloba aqueles que descrevem a topografia. Esses costumam referir-se, nessa região de relevo pouco diferenciado, a elementos e configurações hidrográficos: lagoas (hwambât), praias (kensy), corredeiras (ngôsoko), embocaduras (hwa krari)... Muitos salientam particularidades (cor, opacidade, movimento, aparência geral) da água em certos trechos de rios, lagos ou córregos.

$\begin{array}{ll}\text { Ngô Katátxi } & \text { Kensy Toktxi } \\ \text { água cristalina } & \text { areia morro-AUM } \\ \text { Rio cristalino } & \text { Duna alta } \\ \text { Ngôjhwêrê } & \text { Hwambât Hwa-krat-sï } \\ \text { água-fazer } & \text { lagoa braço começo-pequeno } \\ \text { Nascente do rio } & \text { Lagoa da entrada apertada }\end{array}$


Ngôkre khôrô Wasatang Djêrê

água-buraco POSP ilha pendurada

Ilha pendurada no meio do rio

Uso

Uma outra grande categoria refere-se a usos habituais; neste caso, os nomes em geral constroem-se por meio do elemento tá - aqui com o significado de "lugar" ("de/em que"), mas que entra também na composição de nomes que se referem a instrumentos (traduzindo-se como "coisa de/para"). Como foi mencionado, às vezes é difícil distinguir entre esses nomes e aqueles que se referem a eventos específicos.

Mben Djahôrô Tá

Mel extrair/furar lugar

Lugar de tirar [onde tiraram?] mel
Ngôjrô mã Me Sápiri Tá

atalho POSP gente subir lugar

Lugar de subir [onde subiram?] para o atalho

Hwy Járá Tá

urucum cozinhar lugar

Lugar de cozinhar [onde cozinharam?] urucum

\section{Eventos}

Muitos tipos de evento podem gerar um nome de lugar. Alguns parecem mais "excepcionais" (a percepção da presença ou ação de um animal-espírito, por exemplo), outros mais corriqueiros; uns referem-se a eventos cerimoniais, outros a atividades cotidianas; alguns são o que se reconhece como acontecimentos propriamente históricos, com impactos óbvios sobre a vida coletiva, outros parecem ter um caráter mais 
individual, implicando a biografia de uma pessoa ou família.

Os primeiros exemplos abaixo referem-se a encontros com um tipo de ente que os Kïsêdjê chamam khomndu, termo que traduzem, em português, por bicho da água. Trata-se de um animal-espírito aquático, dito "dono dos peixes" (tep khandê), que seriam sua "criação" (khiri, no sentido de "animal doméstico", "bicho de estimação"). Provocado, causa tempestades, enchentes, turbilhões. Existe sob muitas variedades ou formas, que recebem nomes específicos, compostos por termos referentes a outros animais. Penetrar desavisadamente no domínio desses seres, e perturbá-los, consiste provavelmente em um dos maiores riscos de viagem conhecidos pelos Kïsêdjê.

\section{Khomndu Nõrõ}

bicho-da-água deitar

Leito do Bicho da Água

Há dois lugares (trechos de rio) com este nome. Um no Pacas: quando moravam no Ngôjhwêrê antigo (c. 1950), viram uma vez que a água num certo trecho estava suja e deduziram que ali era morada de Bicho da Água. O outro no Suiá-Miçu: num certo ponto do rio, o pai de Hwandypndo (este um homem com hoje cerca de 55 anos) furou um Bicho da Água com o remo e este quase afundou sua canoa.

\section{Khomndu ra Hwïrãrãk Tá}

bicho-da-água RA árvore-sacudir lugar

Lugar em que o Bicho da Água sacudiu as árvores

Estavam indo para o Ngôsakatxi (rio Parnaíba) tirar urucum e pararam aqui para tirar madeira (quina). Fizeram barulho e de noite um Khomndu fez sacudir [a terra, as árvores]. O lugar tem outros nomes: Hwïkhakhát thãmã (pé de guarantã/quina); Hwïkangêngê khô (grupo de garapeiras)

\section{Khupë Wymba re Mekhrïtá}

índio medo RE acampamento

Acampamento de medo dos inimigos 
Onde os Kïsêdjê se esconderam depois dos ataques yudjá (c. 1915) que resultaram na destruição da aldeia Wawi hwakrari. Foi a partir deste lugar que os Kïsêdjê se dispersaram, parte deles abrigando-se no Alto Xingu, e outra parte subindo o Suiá-Miçu para a região das antigas aldeias Yaruma, vindo a reunir-se algum tempo (anos) depois. Hoje, vêm buscar tucum aqui.

\section{Tutê Jakhárá Tá wê Hwambârâ}

arco cortar lugar COP lagoa

Lagoa do lugar em que cortaram o arco

$\mathrm{Na}$ ilha entre o rio e a lagoa, os Yudjá cortaram o arco de um homem chamado Kokorámõrõtxi, que haviam matado rio acima (no Ngôsakatxi), depois do ataque à aldeia na boca do Wawi [c. 1915].

\section{Amtek Jasôk Tá}

lama amassar lugar

\section{Lugar em que amassaram lama}

Quando moravam no Ngôjhwêrê antigo, viajaram para este lugar e aqui cantaram/dançaram Kahran Kasáká [um repertório próprio da estação seca]. Choveu, e mesmo assim continuaram a cantar, produzindo lama com os pés. [Acompanha-se essa música batendo o pé no chão para marcar o ritmo].

\section{Sáktxi Tantwârâ Tá}

gavião-real flechar lugar

Lugar em que flecharam gavião-real

$\mathrm{Na}$ época em que moravam no Ngôjhwêrê antigo (déc. 1950), estavam acampados aqui quando Ropndo (um homem hoje com mais de 90 anos) matou um gavião-real. É roça antiga, aberta por Petxi (falecido em 1985) quando morava em Rophwika kapajta (déc. 1950). Atualmente serve de acampamento.

Os nomes de lugar kïsêdjê, vê-se, registram eventos e atividades, domínios e populações animais ou vegetais (além de características da 
topo e hidrografias). Sem pretender oferecer uma análise exaustiva, o objetivo dessa descrição panorâmica foi evidenciar a saliência de ações e interações como as registradas nessa última categoria de nomes. Faz parte de meu argumento a ideia de que também os nomes que falam da presença de animais e plantas, como coletivos ou individualidades, identificam menos recursos que sujeitos com os quais trata-se, para os Kïsêdjê, de interagir. Que os nomes sejam registro dessa interação, pretérita ou potencial, ajuda a entender os dois aspectos inicialmente salientados desse sistema: o da instabilidade e mutabilidade dos nomes (Ngrwatxikhô por Rophwïkákapajtá) e o do contexto interpessoal de sua transmissão (sua interatividade narrativa, digamos), no sentido de compreender em que tipo de história estão implicados. Nessa direção, um contraste com a maneira como outras histórias espaciais ameríndias aparecem na literatura pode ser útil.

\section{Histórias}

Fazem duas décadas, Arhem (1998) podia afirmar que as noções de paisagem, território e pertencimento local eram relativamente pouco exploradas na etnografia amazônica. Desde então, uma grande quantidade de estudos têm vindo preencher esta lacuna. Está fora de cogitação recensear aqui esta literatura, ademais agora extremamente variada. Certas particularidades da experiência kïsêdjê, entretanto, parecem-me melhor ressaltadas contra o pano de fundo dos trabalhos sobretudo os da virada do século - concernentes a povos Aruak e outros do Noroeste Amazônico, onde se encontrariam verdadeiras "geografias xamânicas" (a expressão é, parece, de Reichel-Domatoff), no contexto de sociocosmologias que poderiam ser ditas (como as australianas, talvez) "baseadas na paisagem". Essas geografias, associadas a tradições cosmogônicas elaboradas, nos instalam de imediato em uma paisagem densamente histórica, que não se percorre sem topar, a cada curva, com 
evidências e consequências de ações e eventos passados, codificados na toponímia e 'inscritos' dessa maneira na própria terra. Mais recentemente, vale notar, o foco tem se expandido da espacialização das histórias ameríndias para a historicidade de suas espacialidades (VIEIRA, AMOROSO, VIEGAS e 2015; AMOROSO, MENDES DOS SANTOS, 2013). De histórias espaciais a espacialidades históricas, dois aspectos provavelmente inseparáveis - mas é a ênfase de parte significativa da literatura no primeiro aspecto que me serve melhor de revelador e contraste para caso kïsêdjê.

Estes trabalhos sublinham a maneira como os lugares servem de suporte mnemônico a uma história indígena que, expressa simbolicamente no mito, se inscreve assim em um meio material específico, segundo uma lógica determinada: eles devem então ser lidos. Uma análise exemplar é o estudo de Santos-Granero (1998), a propósito dos Yanesha, Aruak sub-andinos. O autor situa sua investigação nos quadros do problema de "how societies remember". Trata-se de mostrar como modos de expressão e transmissão de consciência histórica reconhecidos - mitos, tradições orais, memórias pessoais, performances rituais, hábitos corporais - podem igualmente reunir-se e sustentar uma "major inscribing practice", a escrita da história na paisagem. Essa escritura topográfica, uma espécie de sistema de protoescrita (que pode coexistir ou não com sistemas de escrita verdadeiros), se basearia em topogramas, elementos da paisagem cuja configuração presente seria o resultado das atividades transformativas de seres do passado, humanos ou sobre-humanos. Individualmente, cada topograma evoca um evento ou ideia singular; combinados, por oposição ou conjunção (por exemplo, na saga de um certo personagem mítico), formam sistemas semióticos mais amplos que o autor chama topografos. Santos-Granero identifica entre os Yanesha três diferentes tipos de topograma, segundo o meio pelo qual elementos da paisagem adquirem sua significância/significado: "reminiscências pessoais", "tradições orais coletivas" e "narrativas míticas". Ele argumenta que os dois primeiros só apresentam a necessária 
resistência "às forças erosivas do tempo e do esquecimento" quando integrados em narrativas míticas e assim "sacralizados". Memórias pessoais seriam partilhadas por poucos, portanto de vida breve; tradições orais coletivas não remontariam mais de um século. Seria apenas por meio do

legitimizing power that derives from the sacred nature of myths that particular elements of the landscape are historicized in a collective and, to a large extent, permanent manner, thus becoming true topograms and topographs within a sacred geography (SANTOSGRANERO, 1998, p. 141).

É portanto por meio da narração de mitos e performance de rituais que a história se veria "escrita na paisagem", "transformando assim espaço bruto em uma topografia religiosa que encapsula a memória histórica" (p. 142), pronta a ser "lida" nos marcos geográficos pelos Yanesha em trânsito; e a informação que eles contém pode ser transmitida aos membros das gerações sucessivas.

Que a construção cultural de identidades coletivas por meio do investimento simbólico na paisagem seja uma faceta da criação ativa de lugares (place-making) indígena, é muito provável; que a isso se resuma essa criação, é inverossímil. O rótulo "sagrado" (como em lugares sagrados e geografia sagrada) é sintomático das dificuldades postas pela confusão entre essas duas coisas, e exige manipulação cautelosa. Primeiro, porque a afirmação dos lugares como construção cultural, símbolos de identidades coletivas, parece fácil demais quando corresponde, como é o caso frequentemente, à autodescrição das pessoas. Mas ao parar aqui, as abordagens da paisagem e do lugar como modo de consciência histórica - e/ou ecológica (WHITEHEAD, 2003) arriscam passar muito precipitadamente dessa autodescrição ao discurso das políticas públicas de proteção de patrimônios culturais (e/ou viceversa), subestimando a tensão entre um modo de constituição espacial ancorado na produção arquitetônica, cartográfica, administrativa, 
jurídica, de fronteiras segundo uma lógica de Estado e os modos nativos. Em segundo lugar, e aqui a questão é mais teórica, por fazer ressoar na análise uma dualidade velha conhecida dos antropólogos, o célebre par indivíduo/sociedade e sua dança inacabável; o que faz afinal a diferença entre reminiscências pessoais e consagração mítica, com as tradições orais coletivas situadas a meio caminho? Uma ressonância que se fez às custas das sutilezas dos regimes indígenas de constituição de pessoas e coletivos humanos, emparelhando ademais o par esquecimento/memória à primeira dualidade para completa-la. O problema com essa abordagem não é o fato de se querer histórica, mas sua imaginação restrita de história, reduzida a um passado reificado a serviço da constituição identitária de um coletivo pressuposto. Quem escreve a memória na paisagem? A resposta de Santos-Granero parece ser: a sociedade. Qualquer que seja o valor dessa interpretação para os Yanesha, os Kïsêdjê me parecem apontar outra direção.

Se os Kïsêdjê contam certamente dezenas de histórias que os antropólogos facilmente identificaríamos como mito, e possuem uma categoria nativa de narrativas (methumjê sujareni, "o contar dos antigos") para designá-las, ainda assim seria muitíssimo difícil distingui-las, sem ambiguidade, de tradições orais coletivas, e por vezes mesmo de certas reminiscências pessoais. Narrativas míticas cosmogônicas, remontando às origens do cosmos e da humanidade, tão caras a povos como os Yanesha, foram entre os Kïsêdjê aquelas que menor resistência mostraram às forças erosivas do tempo e do esquecimento. Kuissi, chefe dos Kïsêdjê nos últimos 50 anos, introduz assim um relato (de 2006) das andanças que levaram seu povo até a região do Xingu:

djo adjikatorotá ra mbaj kêrê • nossa origem não se sabe wâtâ kãm na wa adjikato • onde aparecemos adjikatorotá na wi mbaj kêrê • da nossa origem, não se sabe mesmo wâtân adjinhihwêrê • o que fez a gente 
kajkwa-kãm-wapãm na adjinhihwêt jantã • nosso pai do céu que fez a gente, talvez wâtân adjinhihwêrê • o que nos fez... adjikatorotá krat na wi mbaj kêrê • o começo de nosso aparecimento não se sabe ne wa adjipaaa... nhy • nós ficamos existindo ne nhy me ra wa adji kupë ra hwêtri pa • então o pessoal, nós que somos índios, todos ficaram hwêtri paaa... • todos ficaram kupë pamdjê ra djo kajabi, kajapo, kraô, krïkatxi, pinaje, gavião - os antepassados dos índios todos: kajabi, kajapo, krahô, krinkatxi, apinaje, gavião më itadjê ra adji hwêtri adjipaaa... • essa gente nós todos ficamos me ra pa nhy nen $\bullet$ o pessoal ficou

Diferentemente dos Apache, para quem a ideia de eventos que ocorreriam em lugar nenhum é "preposterous and disquieting" "eventos deslocalizados são uma impossibilidade" (BASSO, 1996, p. 86) - meus amigos Kïsêdjê não sabem - afirmam não saber - onde se deram alguns dos acontecimentos mais significativos de sua história: a aquisição do fogo, do milho, a separação das tribos, a abertura das primeiras roças, a obtenção dos nomes pessoais, a adoção da organização nas metades Ambánjê/Krëjê (Piranha/Periquito) e de vários itens do equipamento cerimonial a elas relacionados. Alguns desses acontecimentos recebem, é verdade, uma determinação espacial: margens de um grande rio, no cerrado, na floresta, ao longo de uma longa migração para o oeste... Mas a nomeação de lugares, e sua identificação geográfica, é um componente quase que exclusivo de narrativas já situadas na bacia do Xingu. Entre o presente xinguano e a época formativa da cultura kïsêdjê, contada nesses mitos, estende-se uma segunda etapa da história desse povo, cujo ponto de origem é, em sua própria memória, 
menos um lugar que um conjunto de episódios e encontros guerreiros: tende-se a situá-lo, em todo caso, na região do Tapajós, em função, seja da direcionalidade do movimento migratório (agora de oeste para o leste, invertendo a etapa anterior), seja da identificação retrospectiva dos principais inimigos de então, os Kupësaka e Kupëkryry, aos Munduruku e Panara, respectivamente. O ponto de chegada, por sua vez, são os rios Arraias e Manitsauá, afluentes ocidentais do Xingu. No Arraias (Kasy nhõ Ngô, "rio da castanha"), encontra-se a mais antiga aldeia nomeada dos Kïsêdjê: Kikretxi hwaj Tá ("lugar das casas grandes"). Aqui, acossados e acuados por inimigos, consultam um xamã poderoso, que lhes fala de um grande rio, Ngôtxi ("água grande"), visitado em sonho, com muitas praias, e na ocasião, seco, onde não existiriam "índios bravos", apenas "mansos", habitando as cabeceiras em casas que pareciam ninhos de rato. Tratavase do Xingu. A busca do grande rio é demorada: viajavam no mato, abrindo roças quando chegava a seca; depois de colher a comida, mudavam-se outra vez. Dividiram-se, um grupo seguindo (sem saber) paralelo ao Xingu, o outro indo reto em sua direção. Este último vai dar em uma lagoa ou córrego, e ali acampa. Escutam gaivotas e saem em busca do rio, onde veem grandes praias de areia branca, e concluem ter encontrado o Ngôtxi visualizado pelo xamã. Encontram também terra preta, onde abrem roças. Constroem então a aldeia que depois viria a chamar-se Metyktxi Tá ("lugar de muitos mortos"), em função dos falecimentos resultantes da feitiçaria dos novos vizinhos, os povos do Alto Xingu. ${ }^{7}$

Antes do Xingu, a história kïsêdjê é pensada por eles como um percurso, mas um percurso como que abstraído de uma inscrição geográfica concreta (mas não de direção: os percursos são sempre

\footnotetext{
${ }^{7}$ Esse resumo da história kïsêdjê (e, adiante, as histórias dos três sítios que serão apresentados) condensa dados de várias fontes, entre as quais as principais são Seeger (1981), Ferreira (1994), Pechincha (1996), Frikel (1972), Schultz (1961), Lanna (1961), Von den Steinen (1942[1886]). Apoia-se também em dados de pesquisa, narrativas e depoimentos indígenas; dentre estes, dois longos relatos feitos pelo cacique Kuiussi, o primeiro (2005) no contexto de uma oficina promovida pelo Instituto Socioambiental, e o segundo pessoalmente para mim (2006). Nos dois casos, fora-lhe solicitada uma narrativa de como os Kïsêdjê chegaram ao Xingu.
} 
orientados em relação a um eixo leste-oeste correspondente ao caminho do sol). Eles dizem que não sabem exatamente onde os eventos ocorreram, e isso não importa. Sob esse aspecto, essas narrativas tem um caráter muito diferente das que se referem ao tempo no Xingu e no Suiá-Miçu. Escutemos o cacique Kuiussi, que interrompe seu relato justamente nessa passagem, perguntando-se sobre o que os brancos (parte da audiência nesta ocasião) pensam sobre as histórias que está contando:

Essas histórias vêm desde o início, de antigamente através de nossos ancestrais. A gente não viu o que aconteceu, contamos para vocês o que contaram para a gente. Já aqui no Xingu a gente sabe o que aconteceu porque a gente viu e viveu essa história. Tem velhos aqui, mas não são tão antigos, são próximos de nossas idades. Essas pessoas que estão aqui sabem um pouco mais que a gente, não há uma pessoa que sabe mais (Kuiussi, em narrativa proferida em oficina territorial na aldeia Ngôjhwêrê, 2005).

A partir "daqui" (do Xingu), nomes (de aldeias, rios e roças, notadamente) encadeiam-se na trama que constitui o conjunto de lugares - uma região talvez, como uma "collocation of internally related places" (CASEY, 1996, p. 41) - que se poderia chamar de o "território kïsêdjê". Mas aqui é preciso atentar para a "indefiniteness of the kind of a thing that a place or region is": pois se região refere-se a uma "área concatenada pelas peregrinações entre os lugares que ela conecta" (p. 24) - como na jornada circulatória de uma concha do kula, criada e recriada na unidade espaço-temporal constituída por cada transação específica, na descrição de Munn evocada por Casey (1996, p. 41); sua configuração dependerá evidentemente dessas peregrinações, e de cada um dos eventos (transações, paradas) de que são feitas. O território kïsêdjê é sutilmente diferenciado, e essa diferenciação, assim como sua "indefinição" e abertura, associa-se ao fato de que as memórias que se guardam dos lugares são uma espécie de reminiscência pessoal: "a gente viu e viveu essa história“. Entenda-se: as histórias passadas no Xingu, que remontam 
pelo menos à primeira metade do século XIX, não foram evidentemente vividas por pessoas hoje vivas, mas distinguem-se das mais antigas porque seus protagonistas são em geral identificáveis, não apenas por nomes (que continuam sendo usados hoje em dia), mas por relações de parentesco específicas com aqueles que as narraram para os narradores presentes, que, se não viram o que aconteceu, viram o lugar onde aconteceu, tendo escutado possivelmente in loco, de um pai, tio, avô, uma reminiscência pessoal do acontecido.

A memória dessas relações, dos eventos e interações que as constituíram, está fortemente atrelada aos lugares desses eventos e interações. Talvez se possa dizer que o grau de localização é uma função do grau de aparentamento, isto é, do grau de determinação das relações que constituem o coletivo humano em tal (e não tal outro) lugar, em relação a outras agências e coletivos. O período prexinguano, em que se estabeleceram certas precondições para a existência humana, faz ressaltar também por contraste esses componentes essenciais, ausentes naquele passado, de que depende sua existência presente. Daquele período, há como que uma história só: as diferentes versões (pois, é claro, as há) não remetem a vivências diferentes, de narradores identificáveis à indeterminação espacial corresponde uma indeterminação relacional. No caso dos relatos xinguanos, por outro lado, pode-se dizer que não existe uma história coletiva que não seja também a história de relações especificas entre pessoas específicas em lugares específicos (e essas relações são relações de parentesco). Se levamos em consideração a multiplicidade, riqueza de detalhes, densidade emocional, dos relatos pós-xinguanos, bem como sua saliência do ponto de vista da afirmação de uma identidade kïsêdjê, isso tem lá sua importância. A ideia de uma memória que não se refere nem à unidade, nem a uma simples pluralidade de biografias - mas a um regime biográfico múltiplo, como o é o das relações de parentesco ${ }^{8}-$ me parece ajudar a esclarecer a

\footnotetext{
${ }^{8}$ Uma rede de relações de parentesco nunca é uma, mas sim tantas quanto os pontos de vista que define, e
} 
multiplicidade e plasticidade características dessa toponímia: como uma infinidade de mapas que não representam afinal um território.

\section{Três biografias}

"Por que vocês mudam os nomes dos lugares?" - perguntei certa vez a um amigo que trabalha comigo como assistente de pesquisa, enquanto conversávamos sobre as listas de topônimos.

Penhrêkê: Porque o nome depende do que está acontecendo lá. É por causa da roça... quando o mato cresce de novo. Você sabe, por causa dos ataques de outros índios, ou quando a terra fica fraca, o pessoal mudava sempre de aldeia. Quando voltava para o mesmo lugar, ele já mudou, então vai mudando o nome. MCS: $\mathrm{E}$ o que acontece com os nomes antigos?

Penhrêkê: Os nomes antigos continuam... Por isso um lugar pode ter vários nomes. Os outros nomes não vão embora.

Vejamos alguns exemplos.

\section{Hwinkhôtxi, Hukatsákhrô, Otôkô (Diauarum)}

Em 1884, Karl von den Steinen (1940 e 1942), descendo o Xingu, encontrou os Kïsêdjê na margem direita do rio, a $11^{\circ} 11^{\prime} 04^{\prime \prime}$ de latitude sul, pouco abaixo da boca do afluente hoje conhecido como Suiá-Miçu (precisamente onde se situa agora o Posto Indígena Diauarum). Ele descreve uma aldeia com nove casas, uma casa-dos-homens, e uma população de cerca de 150 almas, cercada de plantações de mandioca e cana-brava. Os Suyá (como eram chamados) dormiam em esteiras ou

\footnotetext{
estes são tantos quanto os pontos que ela une; não há totalização possível, não há apoio para um ponto de vista sociocentrado aqui - um velho problema posto pelo cognatismo para as teorias modernas do parentesco na antropologia...
} 
jiraus, mas tinham cerâmica, redes, flautas, e canoas, adotadas dos altoxinguanos, com quem mantinham já intensas relações cerimoniais, matrimoniais e comerciais.

Os Kïsêdjê chamam o Diauarum (denominação, me dizem, dada pelos Yudjá, e que significa "onça preta") por três diferentes nomes, correspondentes a diferentes fases da história de sua ocupação. Hwinkhôtxi (de hwini, "pequi“) e Hukatsákhrô (de hukatsá, "cana-brava") são nomes antigos - talvez conferidos nessa ordem, conforme os novos moradores foram plantando a cana-brava, especula um de meus interlocutores. Otôkô (de otô, "macaúba") é um nome recente, posterior à instalação ali do posto da expedição Roncador-Xingu pelos irmãos Villas Bôas em 1946. É como se referem hoje ao lugar, empregando a denominação oficial Diauarum apenas quando estão falando com brancos ou outros índios em português.

Hukatsákhrô, ocupada nas últimas décadas do século XIX, parece ter funcionado como uma espécie de polo ao qual se ligavam assentamentos menores. As narrativas mencionam, notadamente, Ndokhërë tá (olho-ingerir lugar; "porque o pessoal comia ovo de tucunaré") ${ }^{9}$ e Hwïkátxi tama, na margem direita do Xingu. Esta última foi a aldeia mais setentrional da história xinguana dos Kïsêdjê, aberta por um homem chamado Nhykramberi, e palco de memoráveis disputas esportivas entre eles e os Wauja. Além dessas três aldeias, os Kïsêdjê ocuparam, na época, pelo menos dois outros sítios, em que abriram roças e construíram abrigos ${ }^{10}$. Um deles chamava-se Kujusi huru ("roça de Kuiussi“), mais tarde rebatizado Monã nhõ ngô, não sei porquê. Acima de

\footnotetext{
${ }^{9}$ Dada por algumas fontes como anterior à Hukatsákhrô (para onde teriam se mudado para evitar ataques trumai); por outras como contemporânea; Kuiussi me conta que foi construída e habitada depois de Hukatsákhrô, mas que sentiram saudades desta última e acabaram voltando para lá.

${ }^{10}$ Os Kïsêdjê chamam esses sítios, em que uma família mantém, além de roças, uma espécie de segunda residência (que pode começar com um simples abrigo e desembocar na construção de uma verdadeira casa), simplesmente de huru, "roça". Vou chamá-los aqui roças-sítio para diferenciá-los dos roçados abertos nas proximidades das aldeias. Essas roças-sítio são muitas vezes o embrião de aldeias-satélites (quando a família em questão abandona de fato a residência na aldeia principal), que por sua vez poderiam constituir embriões de aldeias independentes - teoricamente, pois na história kïsêdjê recente nunca houve mais de uma aldeia principal, se o critério dessa última for algum grau de autonomia cerimonial.
} 
Hwïkátxi tama, ficava Kukhentyk tá (paca-morrer lugar; "lugar em que mataram paca“), onde apareceram pela primeira vez os Manitsawa, povo que os Kïsêdjê chamam Khupëkhô - por isso, o lugar seria também conhecido como Khupëkhô kathorátá ("lugar do aparecimento dos Khupëkhô"). Vitimados por doenças, dizem os Kïsêdjê, esses índios acabaram desaparecendo, sendo seus remanescentes absorvidos por eles"'.

A saída dos Kïsêdjê de Hukatsákhrô e, consequentemente, do Xingu, adentrando o Suiá-Miçu, deveu-se a ataques de dois grupos novos na região, ambos vindos do norte - os Yudjá (Juruna) e os Metyktire (um subgrupo Kayapó) - , bem como a conflitos com seus vizinhos altoxinguanos. Essas tensões iriam ainda condicionar seus deslocamentos na bacia desse segundo rio, ao longo de toda a primeira metade do século $X X$. Os Kïsêdjê nunca, porém, deixaram de frequentar o lugar que passaram então a chamar Otôkô, sobretudo para a coleta dos frutos das palmeiras macaúba e dos pés de pequi que lá haviam plantado.

"Aqui no Xingu a gente sabe o que aconteceu porque a gente viu e viveu essa história. A história de Hukatsákhrô, última aldeia no Xingu, exemplifica certas características dessa espécie de história (e de sua espacialidade particular), no que se refere à relação dinâmica entre ocupação, toponímia e memória. Primeiro, quanto à ocupação, a pluralidade de assentamentos simultâneos, ao longo de uma espécie de contínuo roça-sítio/aldeia satélite/aldeia principal: diferentes estágios de ocupação que podem ser sucessivamente percorridos por um lugar particular (embora não necessários nem absolutamente irreversíveis ${ }^{12}$ ).

\footnotetext{
${ }^{11}$ Outro povo incorporado aos Kïsêdjê durante a fase de Hukatsákhrô (depois de dizimado por conflitos com grupos karib xinguanos), foram os Yaruma (também Karib). As relações dos Kïsêdjê com eles, a quem chamam Kupëtygy ("índio preto"), eram predominantemente amistosas, e há hoje vários kïsêdjê que reconhecem uma ascendência yaruma. Seu território estendia-se até as cabeceiras do Suiá-Miçu; das três aldeias yaruma de que os Kïsêdjê guardam memória (Riktxikô, Hwinkô Jatêntxi e Rikhô Jatentxi), a primeira ficava no Riktxikô nhõ ngô ("rio do inajazal grande"), córrego que deságua no Suiazinho e nasce nas proximidades da BR-080. Os Yaruma entravam por ali para fazer expedições de coleta na região de campo próxima ao território xavante (atual Terra Indígena Maraiwatsede), e em uma dessas viagens capturaram um menino xavante que é pai de um homem kïsêdjê hoje com cerca de 60 anos. Há diversos lugares ao longo do Suiá-Miçu cujos nomes registram a pré-ocupação yaruma.

${ }^{12}$ Não são necessários porque roças-sítio podem $n \tilde{a} o$ se converter em aldeias, e aldeias-satélites podem não
} 
Em segundo lugar, quanto à toponímia, a pluralidade de nomes para um só lugar, com novos nomes sendo atribuídos conforme as circunstâncias da ocupação. Em terceiro lugar, a menção constante a relações de parentesco específicas entre narradores, ouvintes e personagens das narrativas, esses invariavelmente referidos por expressões como atukatxijê ("tua tia/avó") fulana ou angêthumu ("teu avô") sicrano. Se os termos em si não dizem muita coisa - aplicam-se genericamente a todos os parentes pelo menos duas gerações mais velhos - sua conjunção ao nome próprio é informativa, já que as linhas de transmissão onomástica correspondem a relações de parentesco ("o nome pertence à família", dizem em português; ver adiante); e a especificação de parente vivo mais próximo é dada sempre que necessário e possível, no fim da narrativa ou no momento de introdução do personagem. Kuiussi certamente não "viu e viveu" ele mesmo a história de Hukatsákhrô; seu pai, que Ihe contou essa história, tampouco: mas o pai ou avô dele sim. O que permanece vivo em Hwinkhôtxi/Hukatsákhrô/Otôkô não é apenas a memória das histórias em si, mas das relações de parentesco que fazem sua verdadeira trama.

\section{Rikhô, Roptotxi (atual Yaruma)}

Quase ali onde o Pacas deságua no Suiá-Miçu, na margem esquerda, há uma área rica em terra preta, onde a palmeira inajá (riki) cresce em abundância. Quando, na década de 1950, moravam mais acima no mesmo rio, exatamente onde hoje está a aldeia Ngôjhwêrê, este lugar rio abaixo era regularmente usado como acampamento. Chamavam-no Rikhô ("inajazal"). Nos anos 1980/1990, os Kïsêdjê estavam vivendo em uma

\footnotetext{
dar origem a aldeias principais. Quanto à reversibilidade, uma antiga aldeia pode converter-se em uma roçasítio, mas apenas após um longo intervalo, que corresponde à reversão da área aberta em capoeira e desta em mata secundária. Uma conversão desse tipo é o que estava em andamento em Rop hwïká kapajtá em 2007, depois de mais de 50 anos.
} 
aldeia nas margens do Suiá-Miçu, também chamada Rikhô. Em 1999, um ano após a homologação da Terra Indígena Wawi, abriram roça na terra preta do baixo Pacas, com o objetivo de construir uma aldeia próxima ao novo limite, e no ano seguinte ergueram lá a primeira casa. Hoje são oito moradias, reunindo dois irmãos e (alguns de) seus filhos com as respectivas famílias. O filho mais velho do líder da aldeia contou-me como esta foi batizada, na época de sua abertura, com o nome Roptotxi ("raposa grande", "raposão").

Quando o pessoal acampava ali, se não me engano era o pai de Kajutitxi que tinha um papagaio. Fizeram acampamento, barraquinha, e o papagaio aqui no canto. E à noite, ropto veio e pegou o papagaio e matou. Aí o pessoal procurou o papagaio, achou, e o dono do papagaio flechou ropto e matou. Aí nós procuramos [0 nome] - na verdade, o nome de verdade era Rikhô, era para chamar Rikhô, porque tem muito inajá aí. Agora lá, o nome da aldeia velha Rikhô, lá chamava já [Rikhô]. Essa aqui que chamava Rikhô verdadeiro, essa aqui que podia chamar Rikhô. Mas como tem história nesse local aqui, procuramos esse [outro] nome para a gente colocar. Aí meu pai contou [a história] e eu falei: "então vamos chamar Ropto." Primeiro, quando a gente chamava ninguém gostava, [mas] hoje em dia, nossa, Ropto, todo mundo chama... (Maiuri Suyá, depoimento pessoal, 2007).

De fato, o (sítio de) Roptotxi aparece, em outras narrativas, como Rikhô $^{13}$. Não há nada de excepcional nisso: existem, em minha lista de topônimos, muitos exemplos de um mesmo nome para dois, três, ou mesmo mais lugares. Encontramos, por exemplo, cinco lugares nomeados Tyrykhô (de tyry, banana-brava); dois no Pacas, três no SuiáMiçu. Dois designam lugares de acampamento; outros dois, pontos de coleta de recursos (varas); o quinto, "só mato". No Suiá-Miçu, há também três lugares denominados Kensy Toktxi (kensy, areia), dois deles

\footnotetext{
${ }^{13}$ Esse uso se encontra em depoimentos recentemente registrados em relatórios e laudos antropológicos para identificação da Terra Indígena. No contexto de um processo judicial que procurava contestar a ocupação tradicional indígena dessas terras, os advogados dos fazendeiros procuram explorar essa contradição quanto à localização da aldeia Rikhô.
} 
especificados como acampamentos; outros três, no mesmo rio, chamamse Kambêrêkhô (kambêrê, bacaba); e, além de muitos outros exemplos como os anteriores, pelo menos dois córregos são chamados simplesmente Ngôtxire ("riozinho")" ${ }^{14}$. A homonímia não parece portanto ser sempre um problema, mas sem dúvida pode tornar-se um, por exemplo quando o(s) lugar(es) em questão tem a saliência de aldeias ocupadas sucessivamente. Tendo sido reaproveitado para denominar a aldeia dos anos 1980 no Suiá-Miçu, o nome parece ter se tornado indisponível: os moradores de Roptotxi estavam afinal saindo do Rikhô... A situação tem paralelos no que se refere aos nomes pessoais, ao que voltaremos ${ }^{15}$.

\section{Hwinkô(txi), Sáktxi jasê, Ngôjhwêrê}

Quando os Kïsêdjê moravam no médio Suiá-Miçu, em meados da década de 1940, um homem chamado Penkatxi (descrito por Ndêmuntxi, um de meus professores, como um seu "parente verdadeiro"), subira em uma excursão o rio das Pacas e, deparando-se com o sítio onde hoje se situa a aldeia Ngôjhwêrê, "pegou" ( kupy) este lugar - "é como se fosse comprado" (kupy, "pegar", significa hoje também "comprar"). É ele, pois, que encabeça a transferência dos Kïsêdjê do Suiá-Miçu para o alto Pacas, o Ngô Katátxi ("água clara“).

\footnotetext{
${ }^{14}$ Diante desses exemplos, é já difícil decidir se estamos diante de verdadeiros nomes próprios, ou de termos comuns como, por exemplo, wangrá ("terra firme"), que os mais desavisados, obtendo-o como resposta à pergunta "como se chama este lugar?", podem tomar por um topônimo (como obviamente me aconteceu). Com um mínimo de compreensão da língua, e um pouco mais de curiosidade, obtêm-se, no entanto, respostas mais informativas: "não tem nome; é só wangrá mesmo". E o fato que haja situações em que digam isto indica que fazem uma distinção - nos termos da qual Tyrykô, Kambêrêkô e pelo menos um Ngôtxire, mas não o outro, me foram apresentados como verdadeiros nomes - cujo caráter não poderá ser discutido aqui.

${ }^{15}$ A aldeia Roptotxi foi recentemente rebatizada Yaruma. Três dos quatro avós do homem que abriu esse assentamento eram sobreviventes desse povo, incorporados pelos Kïsêdjê. Seu filho, o mesmo que nos conta a história acima, achou por bem usarem o etnônimo, antes que outros xinguanos o tomassem para chamar seus próprios lugares. $\mathrm{O}$ caso tem outras implicações e mereceria em si mesmo uma discussão detalhada.
} 
No sítio do presente Ngôjhwêrê, no caminho para o rio, encontrase um pé de pequi que fica justamente onde erguiam-se as casas da primeira aldeia construída no lugar, antes do contato. ${ }^{16}$ Do porto e lugar de banho, vê-se ainda a entrada do antigo caminho, mais ou menos paralelo ao atual. Duas outras "aldeias" sucederam-se neste mesmo sítio, entre o fim da década de 1940 e 1959: conforme mudavam os arranjos domésticos, alterava-se também a localização das construções. A primeira aldeia tinha duas casas, e um pequeno ngá (casa-dos-homens); a segunda, construída também no atual caminho para o rio, um pouco mais acima, três moradias e um ngá. A terceira foi construída no mesmo terreno da (re)aberta em 2001. A morte de uma mulher que pede para ser enterrada em outro lugar leva algumas famílias, encabeçadas pelo pai do atual cacique, a fundar um segundo assentamento na outra margem do Pacas, cerca de 15 km rio abaixo, no sítio denominado Rop hwïká kapajtá (agora, como vimos, Ngrwatxikhô). Os que ficaram reuniram-se todos em uma única casa, sob a liderança do pai de Ndêmuntxi. Estes dois homens (respectivamente, Pentôtxi e Wetkërë) foram aqueles apresentados e reconhecidos como os dois "chefes" suyá no momento do contato.

Essas aldeias tiveram vários nomes. Kuiussi me diz que o primeiro deles foi, como hoje, Ngôjhwêrê; depois, chamaram-na Hwïnkhô ("pequizal"). Esta parece ter sido a denominação mais utilizada durante o processo de identificação e demarcação dos anos 1990, seja na sua forma linguística indígena, seja na tradução "Pequizal" (PECHINCHA, 1996). Com a finalização do processo, no entanto, Ngôjhwêrê passou a ser oficialmente adotado. Um terceiro nome, dizem alguns outros Kïsêdjê, foi Sáktxi Jasê. As fontes são bastante confusas sobre as denominações desse sítio e sua sequência. Vale notar que Hwïnkhô (-txi, mas o

\footnotetext{
${ }^{16} \mathrm{O}$ Ngôjhwêrê do século XXI, por sua vez, passou por duas fases: na primeira, era formado por um círculo de casas a cerca de 300 metros do rio, que se manteve de 2001 a 2011, quando, em agosto, um incêndio destruiu 17 das 26 construções, incluindo a casa-dos-homens. Um segundo círculo, o dobro da distância do mesmo porto, foi aberto no ano seguinte, e para lá foram todos se deslocando aos poucos, entre 2012-2014. Os moradores do Ngôjhwêrê estão no momento em um novo movimento de mudança, para uma aldeia aberta no ano passado bem mais para o interior da Terra Indígena. Procuram se proteger dos efeitos da soja e seus venenos, que são jogados à sua porta.
} 
aumentativo, aqui como nos nomes pessoais, é mais ou menos opcional) é também um dos nomes do Diauarum, e que Sáktxi Jasê é como se chama uma outra aldeia antiga situada no Suiá-Miçu, alvo, assim como Rop hwïká kapajtá/Ngrwatxikhô, da reivindicação fundiária cujo processo encontra-se hoje paralisado.

\section{Conclusão: vida (e morte) dos nomes}

Esses nomes cambiantes ou repetidos não perturbam os Kïsêdjê pelo menos não enquanto não se sentam para projetá-los em um mapa, defrontando-se então com a necessidade de fazer escolhas "transcontextuais", obrigando-se a adjudicar entre eles, fixar usos e excluir opções: pois na série de nomes alternativos para o mesmo lugar, como me disse Penhrêkê, os nomes não se substituem, acumulam-se: "os nomes antigos continuam... [eles] não vão embora“. Talvez pudéssemos ver este acúmulo, tentativamente, como uma espécie de biografia dos lugares. Há paralelos e contrastes entre isso e o que ocorre na esfera dos nomes pessoais.

Os nomes pessoais kïsêdjê consistem, na verdade, em séries, "aglomerados" ou conjuntos (name-sets) fechados de nomes, em geral semanticamente independentes (há exceções), que são transmitidos em bloco. Esses nomes são partilhados por mais de uma pessoa, e os portadores de nomes de um mesmo conjunto chamam-se entre si de ikrãndy e ikrãthumu, termos que traduzem por "xará mais novo/mais velho". Apenas um dos nomes do conjunto, porém, será habitualmente usado para identificar cada indivíduo. Cada pessoa, assim, é em geral referida por um nome diferente, evitando-se a homonímia - idealmente, quando todos os nomes de um conjunto estão em utilização (i.e., sendo portados por indivíduos vivos), não se nomeiam com eles novos portadores (há, outra vez, exceções). Alguns Kïsêdjê que conheço transmitiram seus próprios nomes, i.e., os nomes pelos quais eram 
chamados e conhecidos, a seus netos, e tomaram novos para si - mas outras pessoas explicam-me que essa prática representa uma inovação. Diferentemente de seus congêneres Timbira, entre os quais os nomes recebidos na infância podem ser substituídos e indivíduos podem abandonar seus nomes por várias razões, os Kïsêdjê conservariam indefinidamente seus primeiros nomes ${ }^{17}$. Tampouco se verifica entre eles a prática de chamar uma pessoa por vários dos nomes de seu conjunto, como Lea (2012) afirma fazerem as mães mebêngôkre com seus filhos (de um homem kïsêdjê que o fazia, disseram-me que era porque tinha vivido um tempo entre aqueles). Não obstante, uma pessoa pode ser chamada por um outro de seus nomes (ou por um apelido) quando o nome principal é interdito para o falante (como no caso de uma criança nomeada segundo sua avó paterna, cujo nome é tabu para sua própria mãe, nora da nominadora). Ocorre assim que parentes próximos chamem a pessoa por apelidos ou por nomes diferentes (mas do mesmo conjunto) dos utilizados pelo restante da comunidade, pela razão acima ou outras nem sempre identificáveis (para tudo isso, ver SEEGER, 1981, p. 136). Mais de um nome para um só referente, mais de um referente para um só nome: são situações que não correspondem ao ideal, mas existem. Agora que os nomes são inscritos em documentos de identidade, alguns Kïsêdjê vêm demonstrando descontentamento com as inconsistências resultantes (irmãos cuja mãe aparece nomeada diferentemente no documento de um e de outro, por exemplo), e maquinando o projeto de fixar de uma vez por todas o nome oficial de cada um, segundo um princípio de correspondência biunívoca: para cada nome, um portador, e vice-versa. Pode-se prever algum desconforto, já que o crescimento populacional resultou numa escassez relativa de nomes, ocasionando

\footnotetext{
${ }^{17}$ Quando um homem, já com filhos adultos e vários netos, é incluído na classe dos "velhos" (wikêni), recebe um nome especial, com o prefixo Wiken-; a conversão implica toda uma inversão de comportamentos entre este homem e um descendente que desempenha um papel especial na cerimônia em questão, a partir da qual o comportamento do velho passa a definir-se por oposição à etiqueta de respeito, contenção e vergonha que comanda o comportamento dos jovens e adultos (SEEGER, 1981, p. 170). Essa prática parece estar sendo descontinuada pelos Kïsêdjê.
} 
disputas em torno dos direitos de diferentes famílias sobre esse ou aquele componente onomástico ${ }^{18}$.

O regime cambiante comum aos nomes pessoais e aos topônimos parece-me sugerir um paralelo entre a biografia das pessoas e a biografia dos lugares: um paralelo que obriga a precisar no que consistiria nesse caso a vida, e, portanto, a morte, de umas como de outros. Suspeito, nesse sentido, que a resposta de meu amigo à pergunta "por que mudam os nomes dos lugares?" - "porque o nome depende do que está acontecendo lá" - signifique não que um lugar, diferentemente de uma pessoa, possa mesmo mudar de nome (permanecendo o mesmos lugar), mas que o que faz dele um lugar (e não outro, ou parte de outro, lugar) é "o que está acontecendo lá": como seus múltiplos habitantes estão interagindo - as espécies vegetais que ali crescem (juntas ou separadas), os animais que nele têm seus buracos, ninhos, leitos, enfim, os seres para quem esses lugares são "aldeias", "matos-do", "rios-do", incluindo outros humanos (antepassados) e (antigos ou correntes) inimigos. Vimos que os topônimos kïsêdjê parecem registrar justamente a presença desses habitantes e os acontecimentos que marcam suas interações. Se estas, todavia, são sempre dinâmicas, se suas configurações são sempre mutantes, por que, ou quando, mudar de nome? A resposta de meu interlocutor aponta para os ataques $(\mathrm{a} / \mathrm{de}$ ) inimigos (quando obrigam a deslocamentos) e a regeneração da floresta: eventos de consequências dramáticas que envolvem uma redefinição total dos termos dessas interações. Algo, digamos, como uma morte: que (eventualmente) libera os nomes para serem utilizados em outro lugar...

Outros povos amazônicos costumam abandonar suas aldeias quando há já lá muitos mortos, ou por ocasião do falecimento daquele cuja presença é catalisadora das relações que tecem a comunidade. Isso não fazem, pelo menos não habitualmente, os Kïsêdjê; mas eles têm

\footnotetext{
18 Os direitos de transmissão parecem exercer-se mais sobre o nome individual do que sobre o conjunto de nomes, mas este não é o lugar para desenvolver o ponto.
} 
também seus modos de deixar para trás seus mortos. A maneira deliberada como os esquecem, recusando-se a pronunciar seus nomes enquanto não os dão outra vez a alguém vivo, e como, esquecendo-os, conservam-nos vivos consigo nos nomes que finalmente reciclam, passa também pelo manejo dos lugares e de seus nomes. Para os Kïsêdjê, não pode haver memória (dos mortos, da história) desincorporada, fora da vida dos lugares - e das pessoas. Isso seria muito perigoso...

Talvez valha a pena aqui uma pequena excursão etnográfica. Longe da Amazônia, a aproximação entre tratamento da paisagem e atitude diante dos mortos é sugestivamente explorada por Simon Harrison (2004), a propósito dos Avatip do rio Sepik na Nova Guiné. O autor chama atenção para a peculiaridade cultural - europeia e moderna - de uma concepção do esquecimento como processo passivo em que as memórias apagam-se por si mesmas, nos quadros da qual o problema fica sendo o de como proteger o passado desse processo natural de erosão; e a solução se constrói na forma de arquivos, monumentos, museus... É inevitável que nossa preocupação com as memórias alheias deixe-se frequentemente marcar por tal concepção, mas outros entendimentos e experiências da natureza da memória e do esquecimento são possíveis. Pode-se perfeitamente, ao inverso, constituir o passado como algo que deve ser ativamente esquecido ${ }^{19}$, e as tecnologias de memória correspondentes seriam antes tecnologias do esquecimento. Não que não o sejam necessariamente em toda parte: mas elas o seriam neste caso reconhecida e deliberadamente. Se a paisagem pode afinal ser um repositório do passado, com função e significado mnemônicos, ela deve também poder desempenhar um importante papel na produção do esquecimento - e assim, do futuro.

Harrison descreve as paisagens do médio Sepik como "forgetful landscapes“ (2004). As alterações constantes do terreno, em boa parte

\footnotetext{
19 Para os Kïsêdjê, "esquecer" não é "não-lembrar", e sim "não saber/ouvir", (mbaj kêrê; mbaj = saber/ouvir; kêrê = não); já "lembrar" (mbaj-kêt kêrêe) é "não não-saber/ouvir".
} 
resultado da ação das águas do rio, produzem uma pobreza relativa de resíduos históricos; o passado permanece comparativamente raso e homogêneo; os Avatip constroem suas vidas em uma terra que se move e deriva, devagar mas continuamente, apagando as marcas de suas vidas pregressas. Se as pessoas são memoriosas, as paisagens em que vivem são esquecidas - ativamente, e em duplo sentido, pois elas ao mesmo tempo esquecem e fazem esquecer. Isso se dá também com a ajuda das pessoas: o apagamento em questão é função dos modos como estas a usam, adaptam e alteram - interagem com ela. Abrindo canais que apenas antecipam ou redirecionam o lento trabalho das águas, usando os processos de regeneração florestal para encobrir ou sinalizar seus movimentos, auxiliando a formação de aterros por meio do plantio de árvores, as pessoas menos constroem do que fazem crescer as paisagens, procurando apagar as marcas de sua ação sobre ela ${ }^{20}$. Harrison descreve, pois, o manejo avatip como uma tecnologia para fazer com que a terra esqueça seus habitantes. Seu princípio diretor básico seria "a thoroughgoing indirection" (p. 143), uma reticência em atuar de forma imediata e identificável sobre a terra, mobilizando em lugar disso intermediários para agir por eles. O autor traça ainda um paralelo entre essa "technology of indirection" (p. 143-144) e uma reticência análoga na atitude perante os mortos, comandada pela compreensão de que os vivos devam desengajar-se ativamente deles, fazendo com que desapareçam na terra...

Creio que nenhum americanista deixaria de reconhecer nessa descrição algo de sua própria experiência das paisagens amazônicas. 0 desengajamento dos mortos, por sua vez, é tema clássico também aqui, desde que Carneiro da Cunha nos chamou atenção para suas implicações teóricas (1978). Mais tarde, Anne-Christine Taylor nos mostrou como esse

\footnotetext{
20 "Thus while the people of the middle Sepik shape and mould their landscape, and presumably have done for centuries, they use methods that borrow — and mimic — the land's own intrinsic process, including its intrinsic process of forgetfulness. They fashion their land in ways that make their alterations disappear, chameleon-like, into the environment, where they become difficult to perceive, or imperceptible" (HARRISON, 2004, p. 142).
} 
desengajamento, o esquecimento e obliteração da imagem, nome e memória dos mortos individuais - a necessidade de lembrar de esquecêlos - envolvia uma despersonalização que era o que permitia, por outro lado, a constante presença dos mortos como Outros privilegiados e exemplares, sob a forma de uma "outra espécie social ou tribo não territorializada e, não-obstante, vizinha" (1993, p. 654 - ênfase minha). Em minhas andanças com os Kïsêdjê, defrontei-me também com uma outra modalidade de presença/ausência dos mortos. Em nossa viagem no Suiá-Miçu, visitamos mais extensamente o sítio de uma das aldeias antigas, explorando suas roças, trilhas e porto. Dois de meus companheiros, depois, falaram-me dessa experiência como o mesmo exato misto de tristeza e excitação: "vendo a plantação deles, o caminho, o porto, parecia que o pessoal antigo estava ali, mas eles eram invisíveis". A tristeza associava-se explicitamente à percepção de alienação dos sítios em questão (fora da terra indígena, no interior de propriedades alheias); a excitação me parecia brotar de uma realização súbita e algo inesperada da parte de meus amigos, de sua implicação no lugar, por meio das marcas visíveis, da presença de seus antepassados invisíveis. Nenhum dos dois homens conhecera as pessoas que habitaram essa aldeia. Eles não estavam simplesmente se lembrando dos mortos. Menos nãoterritorializadas do que talvez reterritorializados, em seu caso, os invisíveis mortos kïsêdjê estavam sensivelmente presentes na paisagem, como o estão nos corpos e mentes vivos de seus descendentes.

Retornei algumas vezes ao Ngrwatxikhô. Uma delas foi em julho de 2010. A roça aberta em 2006 já deixara de dar mandioca; ao lado, uma nova derrubada, que seria queimada em setembro e plantada em seguida; entre as duas, florescentes pés de algodão. Andei com o chefe Kuiussi pela trilha que abrira entre o rancho construído ali e uma outra roça, rio abaixo, em um trecho de terra preta. Mostrou-me os pés de pequi antigos, plantados por seu pai e outros parentes, há mais de 50 anos. Um de seus filhos contou-me depois que encontraram sepulturas dos que aqui tinham morrido antes do contato - e que Kuiussi pretendia construir sobre elas 
sua casa.

A criação da antiga aldeia do Rop hwïká kapajtá, neste mesmo sítio deu-se igualmente, como já foi mencionado, em torno de uma sepultura: quando moravam no Ngôjhwêrê antigo, uma mulher, parente do pai do Kuiussi, subitamente doente, antes de falecer, pediu para ser enterrada neste lugar, pois não queria ficar na terra preta abundante na aldeia em que viviam. Sua morte foi um momento crítico em uma sequência de desconfianças e tensões que levou parte da comunidade a afastar-se, pouco tempo depois, criando essa segunda aldeia justamente onde ela havia sido enterrada. Os Kïsêdjê enterram os mortos, em geral, dentro das casas (indivíduos de prestígio são sepultados no pátio). Dizem-me que, inclusive, houve casos em que, transferindo-se de aldeia, carregaram consigo ossos para reenterrá-los no novo sítio. É perigoso para as crianças sentarem-se sobre essas sepulturas, que ficam bem diante das portas, nos primeiros meses ou um ano após o falecimento (aproximadamente o mesmo período em que os parentes mais próximos guardam luto pelo morto). Depois disso, esquece-se que estão ali. Os mortos tornam-se parte do chão onde se pisa, dorme, come, conversa, brinca; o chão sobre o qual se faz diariamente o parentesco.

São esses os mortos que, evocados nas histórias kïsêdjê, conectam e preenchem os nomes dos lugares; eles são os personagens $e$ os primeiros narradores das histórias, pois como vimos todo topograma kïsêdjê se origina de uma reminiscência pessoal. Para que seu conhecimento do território fosse transmitido para as gerações seguintes, foi necessário o mesmo processo de implicação na paisagem (GOW, 1995) em que consistem as presentes atividades dos vivos - incluindo a atividade de narrar histórias. Esse conhecimento não é algo para ser simplesmente lembrado; assim como foi adquirido por meio das relações no seio das quais os lugares são feitos (modificados fisicamente, experimentados e percebidos corporalmente) e são narrados (narração de que depende a visibilidade/legibillidade dessas modificações), ele deve 
ser incorporado e demonstrado no contexto dessas relações ${ }^{21}$. É por isso que as histórias dos lugares podem ser melhor contadas lá, e assim minhas perguntas sobre a toponímia acabavam resultando sempre, para minha alegria, em deliciosos passeios. É por isso que a parte mais importante do projeto de documentação do território para os Kïsêdjê não é a confecção de mapas, mas a compra de barcos a motor, em que velhos e jovens possam atualizar constantemente suas relações mútuas nos e com os seus lugares.

A instabilidade e variação dos nomes de lugar parece-me função dessa implicação e dessa interanimação entre pessoas e lugares. Lugares que não são compostos de outra coisa que de outros tantos corpos e de suas relações, elas mesmas cambiantes, instáveis, imprevisíveis. Incluindo aquelas entre os próprios Kïsêdjê, e sobretudo entre aquele que conhece e narra a história-nome do lugar e os seus parentes jovens que, como meus companheiros de viagem, se veem implicados na paisagem por este ato de narração. No fim disso tudo, vale esclarecer que as listas de nomes de lugar que obtive são notavelmente similares (embora não idênticas). Mas isso não parece depender de nenhum tipo de sacralização que extraia, das experiências particulares de pessoas determinadas por relações específicas, um significado coletivo independente dessas experiências, pessoas e relações. Entre os Kïsêdjê, o que faz, da história uma história viva são justamente essas particularidades, particularidades em termos das quais se desenham os projetos de futuro sustentados por eles. A arte de manterem-se juntos é a arte de combinar sem subsumir, fazer confluir quando possível e separar quando necessário (ou o inverso), esses projetos vitais, que embora não sejam um não chegam a ser muitos. Afinal, não é a vida, como dizia Clarice Lispector, um "estado

\footnotetext{
${ }^{21}$ Ao modo de outros tipos de conhecimento; como diz Gow, "[...] any trans-morten Piro social process depends on the interiorization of that process as specialized knowledge and its revelation as a sui generis act in the present by a living person. The 'customary ways of the old dead people' are socially efficatious only because they have been detached from the memory of the dead an interiorized as specialist knowledge. They are known and demonstrated; they are not remembered" (GOW, 1999, p. 242).
} 
de contato“ (2009, p. 172)??2.

\section{Referências bibliográficas}

AMOROSO, Marta; MENDES DOS SANTOS, G. (Org.). Paisagens ameríndias, lugares, circuitos e modos de vida na Amazônia. São Paulo: Terceiro Nome, 2013.

ARHEM, Kaj. Landscape, territory and local belonging in Northwest Amazonia. In: LOVELL, N. (Org.). Locality and belonging. Londres: Routledge, 1998. p. 75-98.

BASSO, Keith H. Wisdom sits in places: landscape and language among the Western Apache. Albuquerque: University of New Mexico Press, 1996.

CARNEIRO DA CUNHA, Manuela. Os mortos e os outros: uma análise do sistema funerário e da noção de pessoa entre os índios Krahó. São Paulo: Hucitec, 1978.

CASEY, Edward S. How to get from space to place in a fairly short stretch of time: phenomenological prolegomena. In: FELD, S.; BASSO, K. (Org.). Senses of place. Santa Fe, Novo México: School of American Research Press, 1996. p. 13-52.

COELHO DE SOUZA, Marcela S. Três nomes para um sítio só: a vida dos lugares entre os Kïsêdjê. Comunicação apresentada no IV Congresso da Associação Portuguesa de Antropologia (Painel Convidado VII: Classificar: objectos, sujeitos, acções). Lisboa, 2009.

A vida material das coisas intangíveis. In: LIMA, Edilene C.; COELHO DE SOUZA, Marcela S. (Org.). Conhecimento e cultura: práticas de transformação no mundo indígena. Brasília: Athalaia, 2010. p. 18-49.

Conhecimento indígena e seus conhecedores: uma ciência duas vezes concreta. In: CARNEIRO DA CUNHA, Manuela S.; CESARINO, Pedro (Org.). Políticas culturais e povos indígenas. São Paulo: Cultura Acadêmica, 2014. p. 195-218.

Dois pequenos problemas com a lei: terra intangível para os Kïsêdjê. R@U, São Carlos, v. 9, n. 1, p. 109-130, jan./jun. 2017.

\footnotetext{
${ }^{22}$ Essa definição é evocada por Alexandre Nodari (2014), num texto que vim a conhecer depois da escrita original deste artigo, mas que retorna em tudo o que venho pensando sobre terras e lugares desde então. Em especial essa passagem, que usei de epígrafe em uma outra publicação (COELHO DE SOUZA, 2017): "Todo habitante terrestre é uma rede de parentescos (internas e externas); ele é a construção e manutenção de casas: toda biologia é biografia. O habitat não é só uma categoria biológica, mas uma escolha (ética) vital: todo habitat é um hábito, a consistência que adquire a inter-relação da multiplicidade de seres e intensidades que habitam cada vivente. O hábito do eu é o habitat de muitos; a vida é um "estado de contato", como dizia Clarice [Lispector]" (NODARI, 2014, p. 2).
} 
FERREIRA, Mariana Kawall L. Histórias do Xingu: coletânea de depoimentos dos índios Suyá, Kayabí, Juruna, Trumai, Txucarramãe e Txicão. São Paulo: NHIIUSP/FAPESP, 1994.

FRIKEL, Protásio. Migração, guerra e sobrevivência suyá. Revista de Antropologia, São Paulo, v. 17, n. 20, p. 105-136, 1972.

GOW, Peter. Land, people and paper in Western Amazonia. In: HIRSCH, E.; O'HANLON, M. (Org.). The anthropology of landscape: perspectives on place and space. Oxford: Clarendon Press, 1995. p. 43-62.

Piro designs: painting as meaningful action in an Amazonian lived world. The Journal of the Royal Anthropological Institute, v. 5, n. 2, p. 229-240, 1999.

HARRISON, Simon. Forgetful and memorious landscapes, Social Anthropology, v, 12, n. 2, p. 135-51, 2004.

LANNA, Amadeu Duarte. Aspectos econômicos da organização social dos Suyá. Revista de Antropologia, São Paulo, n. 15/16, p. 35-68, 1967.

LEA, Vanessa R. Riquezas intangíveis de pessoas partíveis: Os Mebengôkre (Kayapó) do Brasil Central. São Paulo: EdUSP, 2012.

LISPECTOR, Clarice. A paixão segundo G.H. Rio de Janeiro: Rocco, 2009 [1964].

NODARI, Alexandre. A( )terra(r) ("Se Gaia tem mil nomes, como você prefere chamála?"). Disponível em: http://osmilnomesdegaia.eco.br/2014/09/01/alexandre-nodari-aterrar/>, 2014. Acesso em: 26 jun. 2018.

PECHINCHA, Mônica Soares. Terra Indígena Wawi: relatório de identificação e delimitação. Brasília: Funai, 1996.

PROUST, Marcel. Du côté de chez Swann. Paris: Flammarion, 2015 [1913].

SANTOS-GRANERO, Fernando. Writing history into the landscape: space, myth and ritual in contemporary Amazonia. American Ethnologist, v. 25, n. 2, p. 128-48, 1998.

SCHULTZ, Harald. Informações etnográficas sobre os índios Suya. Revista do Museu Paulista, NS, v. 13, p. 325-332, 1961.

SEEGER, Anthony. A identidade étnica como processo: os índios suyá e as sociedades do Alto Xingu. Anuário Antropológico, São Paulo, v. 78, p. 156-75, 1980.

Nature and society in Central Brazil: The Suyá Indians of Mato Grosso. Cambridge: Harvard University Press, 1981. Identidade Suyá. Anuário Antropológico, São Paulo, v. 82, p. 194-99, 1984. 
TAYLOR, Anne-Christine. Remembering to forget: identity, mourning and memory among the Jivaro. Man, v. 28, n. 4, p. 653-678, 1993.

VIEIRA, José G; AMOROSO, Marta; VIEGAS, Suzana de Matos. Apresentação Dossiê Transformações das Territorialidades Ameríndias nas Terras Baixas (Brasil). Revista de Antropologia, São Paulo, v. 58, n. 1, 2015.

VON DEN STEINEN, Karl. Entre os Aborígenes do Brasil Central. São Paulo: Departamento de Cultura, 1940 [1894].

O Brasil Central: expedição de 1884 para a exploração do rio Xingu. Rio de Janeiro: Companhia Editora Nacional, 1942 [1886].

WAGNER, Roy. Symbols that stand for themselves. Chicago/London: The University of Chicago, 1986.

Recebido em: 21/07/2017 * Aprovado em: 20/11/2017 * Publicado em: 30/06/2018 